University of St. Thomas, Minnesota

UST Research Online

Finance Faculty Publications

Finance

2011

Foreign Cultures, Sarbanes-Oxley Act and Cross-Delisting

Mary S. Daugherty

Univ of St Thomas, msdaugherty@stthomas.edu

Dobrina Georgieva

University of St. Thomas, Minnesota, geor0116@stthomas.edu

Follow this and additional works at: https://ir.stthomas.edu/ocbfincpub

Part of the Finance and Financial Management Commons

This Article is brought to you for free and open access by the Finance at UST Research Online. It has been accepted for inclusion in Finance Faculty Publications by an authorized administrator of UST Research Online. For more information, please contact asle4660@stthomas.edu. 


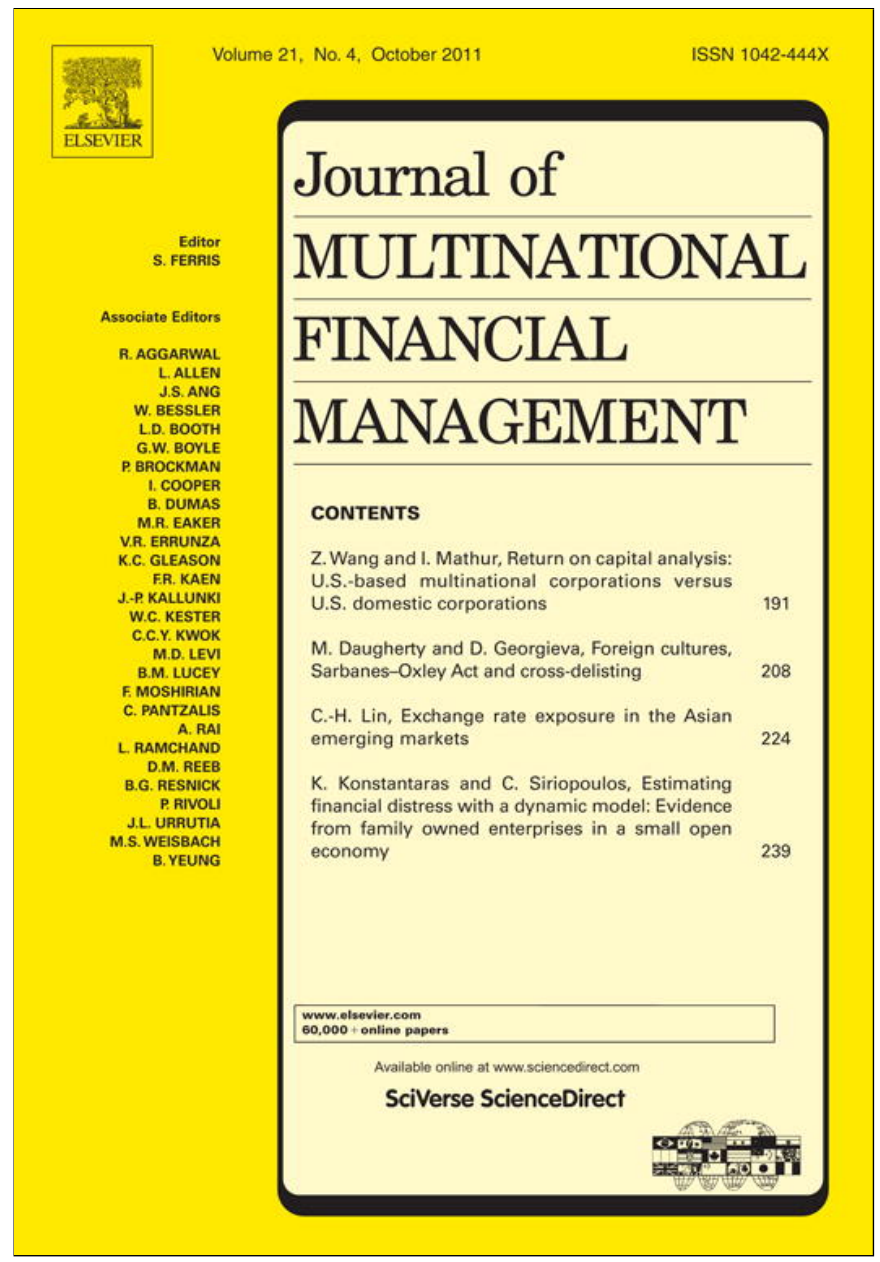

This article appeared in a journal published by Elsevier. The attached copy is furnished to the author for internal non-commercial research and education use, including for instruction at the authors institution and sharing with colleagues.

Other uses, including reproduction and distribution, or selling or licensing copies, or posting to personal, institutional or third party websites are prohibited.

In most cases authors are permitted to post their version of the article (e.g. in Word or Tex form) to their personal website or institutional repository. Authors requiring further information regarding Elsevier's archiving and manuscript policies are encouraged to visit:

http://www.elsevier.com/copyright 


\title{
Foreign cultures, Sarbanes-Oxley Act and cross-delisting
}

\author{
Mary Daugherty ${ }^{1}$, Dobrina Georgieva* \\ Opus College of Business, University of St. Thomas, 2115 Summit Ave., MCH 316, Saint Paul, MN 55105, United States
}

\section{A R T I C L E I N F O}

\section{Article history:}

Received 16 February 2011

Accepted 18 July 2011

Available online 23 July 2011

\section{JEL classification:}

G15

K22

Keywords:

ADRs

Sarbanes-Oxley Act

Delisting

Individualism

Hofstede cultural dimensions

\begin{abstract}
A B S T R A C T
Using a sample of foreign firms listed in U.S. and delisting shares over the period 2000 and 2010, this paper studies the impact of Sarbanes-Oxley Act (SOX) on the cross-delisting behavior of foreign firms based on the firm characteristics, legal tradition, overall culture and degree of individualism of the country of domicile. PreSOX, the propensity to delist is lower for firms from countries with cultural similarities to the U.S. and higher for firms from individualistic societies. Post-SOX these trends are reversed. Consistent with the existing research we find that the delisting decision of foreign firms cross-listed in the U.S. is based on the potential gains from listing based on the growth opportunities, length of presence in the U.S. and legal regulations of the country of domicile. Out findings provide evidence of the cultural factors that impact the competitiveness of U.S. capital markets.
\end{abstract}

(c) 2011 Elsevier B.V. All rights reserved.

\section{Introduction}

Cross-listing behavior of foreign firms has been studied in both the finance and legal literature. Existing research in finance has identified reasons for cross-listing in the United States ranging from greater liquidity, enhanced capital access, increased transparency (Foerster and Karolyi, 1999; Miller, 1999; Doidge, 2004; Doidge et al., 2009b, 2004; Gozzi et al., 2008; Lel and Miller, 2008), to increased visibility and prestige (Fernandez and Ferreira, 2008; Lee and Valero, 2010) among others. The legal literature also offers an explanation; by cross-listing shares in the U.S. foreign firms bond themselves with a stronger legal system which offers better investor protection and leads to increased reputation and higher investor confidence (Coffee, 2002, 1999; Abdallah and Goergen, 2008).

\footnotetext{
* Corresponding author. Tel.: +1 651962 5844; fax: +1 6519625093.

E-mail addresses: msdaugherty@stthomas.edu (M. Daugherty), geor0116@stthomas.edu (D. Georgieva).

1 Tel.: +1 651962 5122; fax: +1 6519625093.
} 
Recently, there has been a trend of foreign delistings suggesting that U.S. has lost competitiveness in the global financial markets (Doidge et al., 2009a, 2010). A common reason often cited is increased compliance cost after Sarbanes-Oxley Act (SOX) of 2002. SOX legislation increased the corporate governance standards, mandating stricter disclosure and monitoring of accounting practices, in effect raising the "rent" of U.S. listing by increasing compliance costs (Marosi and Massoud, 2008; Ribstein, 2003). It benefited firms from countries with poor governance as it provided stronger bonding but at the same time significantly increased the cost of bonding. Post-SOX, foreign firms have been forced to evaluate whether the additional regulatory requirements, with their associated costs, are worth the benefit (Pozen, 2004; Marosi and Massoud, 2008, 2007). SOX mitigates the private benefits of controlling shareholders and prior research suggests that firms delist/deregister when governance standards and investor protection are weak (Leuz et al., 2008).

In this paper we highlight culture as an additional dimension that contributes to the delisting decision of foreign firms. This premise is based on theory from institutional economics suggesting that societal norms and cultural values impact economic interactions (North, 1990; Williamson, 2000). In particular we study cultural similarities between the U.S. and the country of domicile as well as the level of individualism of the home country as a predictor of delisting decision. We focus on culture distance because it is shown to be an important factor in cross-listing activity around the world (Licht, 2003a,b). Companies have a tendency to list in countries that are culturally similar (Pagano et al., 2002), cross-listing activity is clustered regionally (Sarkissian and Schill, 2003), cultural affinities affect economic relationships (Rauch, 2001), and often geographical and cultural factors dominate financial motivations in cross-border security transactions (Portes and Rey, 2000). We define cultural distance following Chakrabarti et al. (2009) as the Cartesian distance between the U.S. and the country of domicile, based on the four most widely used dimensions of culture developed by Hofstede (2001) - power distance, masculinity, uncertainty avoidance and individualism.

In addition we focus on individualism (measured by the individualism index (Hofstede, 1980, 2001)) because it is directly related to the need of bonding with a stronger regulatory environment and therefore the need to end (or maintain) cross-listing. In individualistic societies personal gain is valued higher than the success of the group, leading to a higher risk of agency problems (Fidrmuc and Jacob, 2010) and greater need for bonding with stronger regulations. Individualism is also directly linked to the sense of personal ego and therefore with the overall risk aversion in managerial behavior.

We expect that the impact of culture on the delisting decision will be different pre- and post-SOX. Cultural norms greatly influence the agency relationships across countries (Ekanayake, 2004; Johnson and Droege, 2004; Morris et al., 2001). SOX was introduced to improve transparency and visibility in corporate governance therefore the degree of existing agency problems in a foreign country will influence the need for bonding with SOX legislation (U.S. listing) and therefore impact the delisting reaction to SOX. Pre-SOX greater culture distance leads to a decrease in the willingness of U.S. investors to invest in foreign stocks and therefore we expect that foreign firms will have an incentive to maintain the U.S. listing to gain recognition and therefore easier access to the U.S. capital markets. However postSOX, the cost of compliance might add an incentive for delisting especially for firms from culturally distant countries that need to implement changes in the organizational components of their daily operations in order to comply with SOX.

Furthermore, we expect that the impact of country degree of individualism on delisting will differ pre- and post-SOX. Individualism is associated with confidence and risk-taking behavior (Beugelsdijk and Frijns, 2010; Shupp and Williams, 2008) and we expect that pre-SOX U.S. listed foreign firms from individualistic countries after raising initial capital will have a stronger desire to delist. Likely they will be confident that they will be able to maintain high valuation even without the reputational boost of cross-listing in the U.S. However, those foreign firms that continue to maintain a U.S. listing and face SOX legislature will also exhibit confidence and risk-taking behavior. Confidence in this case is associated with their belief in past decisions and their ability to maintain profitability. These firms will likely continue to maintain a U.S. listing and believe that they will manage to meet the costs of compliance of SOX while maintaining a high valuation. Furthermore, individualistic societies are associated with a higher degree of agency problems and greater need for legal bonding hence the need to maintain the U.S. listing and foreign firms often cross-list in U.S. to improve investor confidence, in 
the home market. SOX requirements provide a boost to investor confidence, increasing the premium for an exchange listing (Litvak, 2007a,b).

Several sections of SOX are directly related to the business practices and culture in the country of domicile. For example, Section 301 of SOX assigns a direct responsibility for accuracy and reliability of financial statements to the CEO yet in several European countries this is performed by the Board of Supervisors. Research in psychology suggests that when a group culture is faced with assigning individual responsibility the overall performance significantly deteriorates (Chen et al., 1998). In several foreign countries the Board of Supervisors is responsible for auditing the financials while SOX requires independent outside auditors. This requirement is in direct contrast to the foreign countries norms suggesting that the informal networking channels in foreign country may function better than adherence to strictly mandated rules of SOX.

Consistent with our expectations, our results suggest that culture distance and the level of individualism exhibited by a foreign country does impact the firm's likelihood to cross-list and eventually delist after the SOX legislation. Pre-SOX firms from countries with cultural similarities to the U.S. were less likely to delist while firms from individualistic societies exhibited a higher overall propensity of delisting. SOX legislation introduced a shift in the costs/benefits of listing and we observe that culture characteristics lead to reversal of fortunes - our results suggest that post-SOX firms from countries with cultural similarities to the U.S. are more likely to delist and firms from individualistic societies are less likely to delist.

Overall, in this paper we provide a possible explanation for the loss of competitiveness of U.S. capital markets. Our study suggests that in addition to the well established research on cost/benefit of crosslisting on the U.S. market from a legal and financial perspective, culture and a measure of investor confidence impact the propensity of foreign firms to delist shares from the U.S. capital markets. The SOX legislation created an opportunity to evaluate a shift in this set of determinants. In fact U.S. is "culturally distant" from more than three quarters of the countries in our sample that have a distance score from U.S. larger than half of the maximums. While pre-SOX cultural distance seemed to be a determinant for cross-listing in U.S., post-SOX cultural differences lead to delisting.

SOX itself is not the only reason for the potential loss of competitiveness of U.S. capital markets. In facts regulations similar to SOX are already implemented in foreign countries (such as C-SOX for firms listed in Canadian and similarly J-SOX for Japan). Also, culture on its own does not motivate the delisting behavior. It is combination of the "distant" U.S. culture and strict U.S. legislature that contributed to the delisting behavior of foreign firms among other factors. This is important as it allows to better understand the factors that motivate a public company's listing/delisting decision, investor preference and thus make conclusions about comparison of exchanges around the world. Ultimately, social ties and informal institutions in a society function better, and may lead to better performance than adherence to formally mandated rules. This topic has received little to no attention in the literature and may explain the choice of listing location in response to the SOX legislation among firms from different countries.

This paper is organized as follows: Section 2 provides a literature review of the cross-listing and delisting process and the impact of SOX including the existing hypotheses from the cross-listing and delisting literature, Section 3 provides the hypotheses development of this paper, Section 4 discusses the data and Section 5 discusses the empirical results. Concluding remarks follow in Section 6.

\section{Literature review}

\subsection{Value impact of cross-listing and delisting}

There was a large number of cross-listed firms in the 1990s and early 2000 and there is extensive literature on the benefits for non-U.S. firms to cross-list shares in the U.S. - firms gain access to more developed capital markets, increased transparency (Foerster and Karolyi, 1999; Doidge et al., 2009b; Gozzi et al., 2008; Lel and Miller, 2008). Lee and Valero (2010) show the increase in the intensity of analyst coverage of ADR programs and this coverage is strongly pronounced for exchange listed ADRs. 
By cross-listing in the U.S. foreign firms overcome market segmentation and most importantly, bond with the U.S. legal regulatory environment, considered stricter and more informative (Doidge et al., 2004; Doidge, 2004; Coffee, 1999; Reese and Weisbach, 2002).

There are various explanations why foreign firms cross-list in the U.S. According to the bonding hypothesis, foreign firms list in the U.S. to legally bond themselves with a stronger regulatory environment, which is a form of functional convergence (Coffee, 1999, 2002) while the firm maintains its listing in the home market, thus allowing testing of both systems. Typically, firms from countries with weak investor protection cross-list on markets with stronger protection (Abdallah and Goergen, 2008). Similarly, Lee and Valero (2010) show the increase in analyst coverage for ADR programs is mostly for firms from countries with greater information asymmetry and weaker legal traditions. With crosslisting foreign firms can "leapfrog" their country's weak legal institutions by listing equity in the U.S. and voluntarily abiding by U.S. security laws (Siegel, 2005). However, this assumes that the destination country's regulatory structures can be transplanted which does not always work well (Licht, 2003a,b). The opposing view from bonding is that firms apply an "avoiding hypothesis" suggesting that firms purposely avoid cross-listing in more highly regulated countries. Many foreign firms that list in the U.S. are required to comply with strict disclosure requirements that require much more information than their respective domestic country. Compliance with this regulation sends a positive signal and therefore is beneficial to the company (Fuerst, 1998). Furthermore, listing in U.S. leads to a decreased overall risk. Akhigbe et al. (2009) show that the capital market measures of total risk and unsystematic risk decreased during the three-year period following the adoption of SOX, suggesting that investor uncertainty was reduced and therefore the markets post-SOX.

Another well cited reason for firms to choose to cross-list is to take advantage of less expensive sources of capital away from their home country or simply to increase the number of potential capital sources. Firms cross-list to achieve access to a more developed capital market reducing the dependence on internally generated cash flows. Often the U.S. capital markets provide opportunities for firms to raise capital at lower costs. The U.S. also has the added benefit of a more developed capital market offering more liquidity, depth, and an enhanced shareholder base (Lins et al., 2003). Firms with higher growth opportunities should receive higher benefits from cross-listing and research supports this, by showing that U.S. cross-listed firms have a Tobin's $Q$ seventeen percent higher than foreign firms that are not cross-listed in U.S. (Doidge et al., 2004). ${ }^{2}$

The set of benefits from a U.S. listing is partially offset by the costs associated with the implementation of SOX in 2002 which raised questions on the competitiveness of U.S. capital markets (Marosi and Massoud, 2008). Cross-listing is associated with additional compliance and exchange listing costs. Cross-listing should be optimal if the benefits exceed the costs. Pre-SOX, the Securities and Exchange Commission (SEC) treated foreign issuers differently than domestic issuers (Perino, 2005). However, when SOX was approved by Congress, the same disclosure and corporate governance requirements were applied to both domestic and foreign issuers. The implementation of SOX generates substantial costs of compliance related to additional legal fees, disclosure, auditing and corporate restructuring (Perino, 2005; Riebstein, 2003). Furthermore, Witmer (2006) shows that firms are more likely to voluntarily cross-delist after 2001, overall firms that cross-delist have a higher proportion of trading volume in their home market, the firms are from countries with weaker investor protection, and they exhibit lower Tobin's Q. Piotroski and Srinivasan (2008) and Witmer (2006) all report increased levels of foreign delistings following the adoption of SOX. These delistings are attributable primarily to sharp increase in compliance costs associated with SOX (e.g. Zhang, 2007; Linck et al., 2009; Wintoki, 2007), foreign listings have been shown to enhance the value of the firm though cross-listing premium. It follows naturally, that foreign delisting from U.S. markets should reduce firm value. Liu (2004) shows that

\footnotetext{
${ }^{2}$ Further, Doidge (2004) provides support for bonding hypothesis by showing that foreign firms that cross-list shares in U.S. have voting premiums that are $43 \%$ higher than foreign firms that do not cross-list - explained by lower private benefits of control for majority shareholders that cross-list in U.S. Along the same lines, Doidge et al. (2009b) show that firms with controlling insiders that have higher controlling rights in relation to cash flow rights are less likely to seek listing in U.S.
} 
there has been a significant drop in stock prices upon the announcement of a delisting decision. ${ }^{3}$ Litvak (2007a,b) shows that firms cross-listed on U.S. exchanges experienced significant negative abnormal returns in response to the passage of SOX legislation. Several authors document the trend of foreign delistings from U.S. capital markets primarily for small firms, lower growth opportunities and from countries with weaker investor protection (Marosi and Massoud, 2008; Piotroski and Srinivasan, 2008; Witmer, 2006). Furthermore, Piotroski and Srinivasan (2008) show that U.S. exchanges experienced outflow of foreign listings except for large profitable firms from emerging markets.

More recently, Doidge et al. (2010) show that foreign firms cross-listed in the U.S. delist for several reasons - they have low growth opportunities (current and future) or they no longer require external funds to finance their growth. Cross-listing in U.S. provides protection to minority shareholders and limits the private benefits of control, hence firms delist when there is insider dominance in the decision making, allowing insiders to gain more benefits after delisting (Doidge et al., 2010).

\subsection{The impact of culture}

It has been suggested in the literature that the traditional explanation for cross-listing and delisting behavior do not completely explain the full array of factors that drive the motivation to cross-list or delist (Licht, 2003a,b). It has been observed that companies cross-list in countries that are culturally similar (Pagano et al., 2002). It is also evident that companies prefer to cross-list in countries that are familiar in geography, language, business structure, common history, etc. (Sarkissian and Schill, 2003). But even with this information it is not obvious how and why some companies chose to cross-list in the U.S. versus other countries. The idea of measuring cultural similarity is more challenging yet we know that culture has an impact on investor behavior (Chui et al., 2010).

Among the cultural dimensions developed by Hofstede (2003), individualism is the most closely related to overconfidence and self-attribution bias and therefore can be used as a proxy for investor self-confidence (Chui et al., 2010). In addition to confidence, a highly individualistic mentality leads to ambition and strong determination in pursuing personal goals, interests (including maximizing their private benefits) and therefore individualistic societies are associated with higher agency cost (Fidrmuc and Jacob, 2008). Hence we focus our study on the impact of the individualism index on the cross-delisting behavior of foreign firms pre- and post-SOX.

There are numerous studies in the psychology literature explaining the components of individualistic versus collectivistic societies and the differences in decision making in these two cultural groups. In this paper we focus on the impact of culture and SOX on the decision to delist. Several requirements of SOX directly contradict practices in foreign countries. For example, Section 301 of SOX requires issuers to have a wholly independent audit committee that hires and oversees the auditors and to maintain that independent status by changing auditors periodically. Contrary to this requirement, supervisory boards of companies in some foreign countries (e.g. Germany) are allowed to appoint auditors at the annual shareholder meeting (Riebstein, 2003). In addition, Section 302 of SOX allocates ultimate responsibility for the accuracy of the firm's financial statements to the CEO and CFO, while in some foreign countries this task resides with the board (Perino, 2005).

Also, human resources and hiring practices differ across countries based on the level of individualism/collectivism. In individualistic countries, hiring is based on the rational models that predict the potential for successful job performance of the candidate (Muchinsky, 2000). In collectivistic societies, on the other hand, the hiring decision is based on long standing relationships and commitments. Triandis and Vassiliou (1972) show that, for example in Greece, upon hiring employers gave preferential weight to friends and relatives recommendation as opposed to objectively evaluating the potential of the candidates. Furthermore, Erez (1994) shows that in collectivistic cultures jobs tend to be organized around a cohesive work group. This is in direct contrast to the SOX requirement that the CEO and CFO sign off on the accuracy of financial reporting as opposed to a team.

\footnotetext{
${ }^{3}$ Delisting U.S. firms experience stock prices drop of 8.5\% after delisting from exchange trading, shareholders face a tremendous increase in trading, a significant decline in liquidity and loss in shareholder wealth (Sanger and Peterson, 1990; Angel et al., 2004).
} 
Kashima and Callan (1994) show that in collectivist cultures decisions are more likely to be made by a group and Chen et al. (1998) point out that in collectivist societies decisions will not be optimal if a culpable individual can be identified.

\section{Hypotheses development}

\subsection{The impact of culture}

While the propensity of firms to cross-list is based on raising capital, access to a broader investor base and differences in legal regulations, these reasons do not explain the behavior of firms over time nor do they account for other variables not directly observable in legal bonding or financial benefits research. Licht (2003a,b) refers to cross-listing as "legal transplants" and suggests the fit between the country of domicile overall investor attitude (here described as culture) will play a role in the firm's decision to cross-list and subsequently delist. Finance literature has already shown the increased likelihood of listing in a culturally similar foreign environment (Pagano et al., 2001).

A greater cultural distance is associated with less familiarity (Beugelsdijk and Frijns, 2010) and Huberman (2001) suggests that domestic investors familiar with their domestic markets and stocks may feel a sense of discomfort of owning foreign stocks. Furthermore, greater cultural distance may lead to not even investing in the foreign stocks (Loree and Guisinger, 1995; Sethi et al., 2003). Therefore cross-listing in the U.S. is a mechanism through which foreign stocks gain recognition in the U.S. and overcome cultural distance. Therefore we expect that:

H1. Firms from countries culturally distant from the U.S. are less likely to delist.

Furthermore, we focus on one specific dimensions of culture - individualism which is the most comprehensive and widely studied variable among Hofstede's five cultural dimensions (Chui et al., 2010). Individualism measures the extent to which people rely on themselves and their own ability as opposed to the success of a group. Individualism is highly correlated with the ability to take risk. Cross-listing in the U.S. offers a set of bonding benefits and therefore delisting will be associated with a potential risk of losing the investor trust and high valuation (that came with the initial cross-listing). Individualism is related to tendency for risk taking (Beugelsdijk and Frijns, 2010). Furthermore, Shupp and Williams (2008) find that groups are more risk averse than individuals in high risk situations and that therefore we expect that managers from highly individualistic countries will exhibit risk taking behavior.

Based on studies from the psychology literature, there is a direct relationship between individualistic mentality and investor confidence (Chui et al., 2010) and therefore we expect that firms from countries with a higher individualism score will have a higher confidence in their ability to succeed after the initial reputation boost of listing shares in the U.S. and will be more likely to subsequently delist.

H2. Firms from individualistic societies are more likely to delist.

\subsection{Culture and SOX}

The passage of SOX leads to strengthening of the disclosure requirements for all firms (including foreign issuers) and better monitoring and control of accounting practices. It brings a new set of legal requirements that may lead to reorganization of the business practices especially for firms from countries in which SOX contradicts commonly accepted organization routines. In fact, SOX brings a shift in corporate culture and we expect that post-SOX the culture of the country of domicile will have an impact on the delisting behavior of foreign firms. Foreign firms listed in the U.S. are subject to the same requirements as domestic firms which include organizational components such as requiring independent auditors and assigning responsibility for the accuracy and reliability of financial reports to the CEO. Foreign firms listed in the U.S. will be mandated to comply with SOX and therefore change their practices and eliminate corporate behavior that might be specific to their culture. Because of the 
high cost of compliance with U.S. regulations post-SOX, specifically for countries with high cultural distance from the U.S. we expect that these firms will seek alternative source of capital and visibility and thus:

H3. Post-SOX, firms from countries culturally distant from the U.S. are more likely to delist.

Furthermore, the passage of SOX creates a confidence boost for the firms that were able to sustain their U.S. listing and comply with SOX regulations. This is particularly true for the investors in the country of domicile of the foreign firms cross-listing in the U.S. One of the consequences of SOX was the improved investor confidence in the home country of firms cross-listed in the U.S. (Litvak, 2007a,b). Because individualism is closely related to confidence we expect that SOX will impact the propensity of foreign delisting based on the level of individualism in the country of domicile. Foreign firms from individualistic countries listed in the U.S. will have the confidence that they will be able to manage SOX compliance and remain competitive and therefore will not flee the U.S. post-SOX. Confidence is associated with faith in past decisions and the ability to maintain profitability. Further, firms from individualistic societies are associated with higher degree of agency (Fidrmuc and Jacob, 2010) and complying with SOX regulation sends a strong signal to investors, possibly mitigating the cost of information asymmetry and ultimately maintaining listing in the U.S. post-SOX as the desirable outcome. Therefore we expect that:

H4. Post-SOX, firms from individualistic countries are less likely to delist.

\subsection{Value implications}

Doidge et al. (2004) show that there is a cross-listing premium for foreign firms cross-listing in the U.S. The process of delisting from the U.S. capital markets is associated with a delisting discount. However, post-SOX foreign firms listed in the U.S. might be searching for alternative locations for crosslisting due to the high compliance costs associated with SOX. Therefore, we expect the implementation of SOX will not significantly impact the delisting discount.

H5. SOX does not significantly impact the delisting discount of foreign firms that are cross-delisting from U.S. capital markets.

\section{Sample description}

Data of delisted ADR programs is provided by the Bank of New York. The data contains 1419 foreign ADRs and 287 companies with terminated ADR programs between 2000 and 2010. The file provides the initiation date for each ADR program and the termination date. In addition, this file is matched and cross-checked with data from CitiBank in order to obtain the complete list of terminated depository receipt programs in the U.S.

For each of these firms, annual accounting data is retrieved from Compustat Global. Country-specific variables are obtained from Djankov et al. (2008).

To find the determinants of the ADR terminations we compare the characteristics of foreign companies that terminate their ADRs with a control sample of all foreign firms that have currently active ADR programs regardless of the time they originally listed. The sample of foreign firms with terminated ADRs consists of 287 firms terminating their ADRs between 2000 and 2010, and the control sample consists of 1419 active ADRs. Foreign firms can sell their shares on the NYSE, NASDAQ OTC market and using PORTAL - private placements to qualified institution buyers (QIB).

Cross-listing in the U.S. is possible through four sponsoring banks - Bank of New York, CitiBank, Deutsche Bank, and J.P. Morgan Chase. Table 1 shows the firms in the listed and delisted sample by country - this table is by firm year level presenting the average Market-to-Book and assets for the observations from the panel data. On average, delisting firms have lower Marketto-Book, consistent with the notion of a cross-listing premium (and therefore, cross-delisting discount). 
Table 1

Sample description. Firm year data on cross-listed and delisted firms.

\begin{tabular}{|c|c|c|c|c|c|c|c|c|c|}
\hline & \multicolumn{3}{|c|}{$\begin{array}{l}\text { Cross-listed during } \\
\text { sample period }\end{array}$} & \multicolumn{3}{|c|}{$\begin{array}{l}\text { Delisted during sample } \\
\text { period }\end{array}$} & \multirow{2}{*}{$\begin{array}{l}\text { Revised } \\
\text { antidirector } \\
\text { index }\end{array}$} & \multirow[t]{2}{*}{$\begin{array}{l}\text { Culture } \\
\text { distance }\end{array}$} & \multirow[t]{2}{*}{$\begin{array}{l}\text { Indivi- } \\
\text { dualism }\end{array}$} \\
\hline & $N$ & $\mathrm{MB}$ & Assets & $N$ & $\mathrm{MB}$ & Assets & & & \\
\hline Argentina & 14 & 1.20 & $\$ 18,568.05$ & 4 & 0.85 & $\$ 3,813.44$ & 0.34 & 15.29 & 46 \\
\hline Australia & 164 & 2.10 & $\$ 1,586.20$ & 26 & 2.16 & $\$ 2,007.51$ & 0.76 & 1.64 & 90 \\
\hline Austria & 16 & 1.35 & $\$ 10,596.19$ & 4 & 1.26 & $\$ 1,142.61$ & 0.21 & 13.70 & 55 \\
\hline Belgium & 19 & 1.50 & $\$ 30,819.52$ & 1 & 1.00 & $\$ 1,690.24$ & 0.54 & 14.25 & 75 \\
\hline Brazil & 42 & 2.61 & $\$ 59,575.34$ & 16 & 1.77 & $\$ 4,959.32$ & 0.27 & 17.17 & 38 \\
\hline Chile & 7 & 2.34 & $\$ 701,308.75$ & 8 & 3.29 & $\$ 626,976.53$ & 0.63 & 22.23 & 23 \\
\hline Denmark & 15 & 2.00 & $\$ 12,854.05$ & 2 & 1.30 & $\$ 64,999.78$ & 0.46 & 14.62 & 74 \\
\hline Egypt & & & & 1 & 2.52 & $\$ 45,302.74$ & 0.20 & & \\
\hline Finland & 21 & 1.34 & $\$ 8,986.28$ & & & & 0.46 & 11.98 & 63 \\
\hline France & 58 & 1.55 & $\$ 24,215.27$ & 14 & 1.32 & $\$ 2,058.06$ & 0.38 & 14.02 & 71 \\
\hline Germany & 53 & 1.50 & $\$ 14,506.23$ & 14 & 2.06 & $\$ 732.87$ & 0.28 & 7.82 & 67 \\
\hline Greece & 10 & 2.05 & $\$ 136,157.51$ & & & & 0.22 & 22.24 & 35 \\
\hline Hong Kong & 38 & 1.73 & $\$ 14,994.94$ & 4 & 1.00 & $\$ 10,446.31$ & 0.96 & 18.46 & 25 \\
\hline India & 101 & 1.37 & $\$ 45,283.54$ & 5 & 2.07 & $\$ 41,951.77$ & 0.58 & 14.34 & 48 \\
\hline Ireland & 10 & 1.53 & $\$ 9,132.82$ & 5 & 1.45 & $\$ 1,468.76$ & 0.79 & 6.81 & 70 \\
\hline Israel & 15 & 2.44 & $\$ 5,647.85$ & 2 & 1.05 & $\$ 5,925.13$ & 0.73 & 14.89 & 54 \\
\hline Italy & 28 & 1.32 & $\$ 856,849.80$ & 6 & 1.29 & $\$ 375.92$ & 0.42 & 8.77 & 76 \\
\hline Japan & 217 & 1.43 & $\$ 1,011,877.18$ & 19 & 1.28 & $\$ 1,062,738.95$ & 0.50 & 18.42 & 46 \\
\hline Korea & 10 & 1.25 & $\$ 2,310,372.41$ & & & & 0.47 & 22.05 & 18 \\
\hline Luxembourg & 2 & 2.32 & $\$ 111,814.27$ & 5 & 1.31 & $\$ 17,978.23$ & 0.28 & 10.25 & 60 \\
\hline Malaysia & 8 & 1.38 & $\$ 9,475.11$ & 4 & 1.57 & $\$ 16,193.48$ & 0.95 & 23.14 & 26 \\
\hline Mexico & 27 & 1.22 & $\$ 82,837.02$ & 15 & 1.24 & $\$ 17,701.64$ & 0.17 & 20.54 & 30 \\
\hline Netherlands & 23 & 1.68 & $\$ 11,988.70$ & 13 & 1.17 & $\$ 2,086.19$ & 0.20 & 12.44 & 80 \\
\hline New Zealand & 26 & 1.63 & $\$ 1,807.71$ & 4 & 0.90 & $\$ 282.29$ & 0.95 & 5.55 & 79 \\
\hline Norway & 23 & 2.05 & $\$ 32,228.72$ & 5 & 1.19 & $\$ 4,454.03$ & 0.42 & 14.78 & 69 \\
\hline Philippines & 10 & 1.16 & $\$ 82,392.20$ & 2 & 1.21 & $\$ 38,927.28$ & 0.22 & 20.01 & 32 \\
\hline Poland & 11 & 1.49 & $\$ 5,590.76$ & 4 & 1.09 & $\$ 17,776.60$ & 0.29 & 15.73 & 60 \\
\hline Portugal & 13 & 1.16 & $\$ 203,297.41$ & 1 & 1.49 & $\$ 4,043.35$ & 0.44 & 23.65 & 27 \\
\hline Russia & 39 & 0.98 & $\$ 95,556.05$ & 4 & 0.69 & $\$ 88,325.29$ & 0.44 & 23.17 & 39 \\
\hline Singapore & 47 & 1.68 & $\$ 38,895.35$ & 1 & 5.64 & $\$ 1,591.62$ & 1.00 & 22.13 & 20 \\
\hline $\begin{array}{l}\text { Slovak } \\
\text { Republic }\end{array}$ & & 0.72 & $\$ 54,152.63$ & 1 & 1.05 & $\$ 56,773.17$ & 0.29 & 22.29 & 52 \\
\hline South Africa & 50 & 1.76 & $\$ 11,557.28$ & 10 & 1.74 & $\$ 21,095.75$ & 0.81 & 6.92 & 65 \\
\hline Spain & 24 & 1.45 & $\$ 295,572.82$ & 3 & 1.22 & $\$ 279,396.38$ & 0.37 & 15.59 & 51 \\
\hline Sweden & 27 & 1.74 & $\$ 25,349.30$ & 4 & 2.61 & $\$ 1,378.62$ & 0.33 & 15.85 & 71 \\
\hline Switzerland & 24 & 2.11 & $\$ 7,367.69$ & 4 & 2.64 & $\$ 18,298.74$ & 0.27 & 6.95 & 68 \\
\hline Taiwan & 33 & 1.62 & $\$ 115,410.59$ & 8 & 1.20 & $\$ 98,256.91$ & 0.56 & 20.34 & 17 \\
\hline Thailand & 12 & 1.52 & $\$ 39,662.88$ & & & & 0.81 & 20.50 & 20 \\
\hline Turkey & 19 & 1.98 & $\$ 1,185,478.10$ & & & & 0.43 & 18.37 & 37 \\
\hline $\begin{array}{l}\text { United } \\
\text { Kingdom }\end{array}$ & 161 & 1.89 & $\$ 4,212.70$ & 65 & 1.88 & $\$ 2,194.05$ & 0.95 & 3.22 & 89 \\
\hline Venezuela & 2 & 1.28 & $\$ 691,861.45$ & 3 & 0.71 & $\$ 14,537.63$ & 0.09 & 23.64 & 12 \\
\hline
\end{tabular}

This table reports the number, average Market-to-Book, and average assets for foreign firms that listed and delisted in (or from) the U.S. over the sample period 2000-2004. Market-to-Book is calculated as (Total assets - Book equity + Market value of equity)/Total assets. Revised antidirector rights index is from Djankov et al. (2008). Culture distance is measured as the Cartesian distance (based on four cultural dimensions) between U.S. and the country of domicile. Individualism index is from Hofstede (1991).

Table 1 shows the number of delisted firms and the number of firms maintaining a U.S. listing by country during our sample period. Consistent with other studies, the highest number of cross-listed firms come from Japan, United Kingdom, Australia, India and France and the highest number of delisted firms is from the United Kingdom, Australia, Japan, Brazil and Mexico. 


\section{Empirical results}

\subsection{Determinants of cross-delisting and impact of SOX}

In this section we study the propensity of foreign firms already listed in U.S. markets to delist. We build on the existing model of cross-listing, based on the legal system of the country of domicile and growth opportunities (Doidge et al., 2009a,b) and add cultural variables. The decision to delist is determined by several company and country specific factors. The company specific factors measure the growth opportunities through Market-to-Book, two-year annualized Sales Growth, and the age of the listing of the firms. We use leverage (measured as debt/assets) as a control variable. The legal origin dummy variable measures whether the firm belongs to a country with civil or common legal origin and we use the revised anti-director rights index (Djankov et al., 2008) to measure the level of shareholder protection in foreign countries. And last, we add a measure of the cultural distance and individualism index. We define culture distance as the Cartesian difference of the culture dimension variables. Hofstede has defined 5 culture variables (dimensions) and in fact 4 of them are reasonable proxies for the dimensions of cultural development - power distance, masculinity, uncertainty avoidance and individualism (the 5th one - long term orientation - was created later for a limited set of countries and is not widely used). We followed the approach of Chakrabarti et al. (2009) who use the Cartesian difference between the four dimensions of culture and thus constructed a single variable that is used as a proxy for culture differences. We use a logit regression model of the following form:

Likelihood of ADR termination $=f[$ Assets, Leverage, Market-to-Book, Sales growth,

age dummy, SOX, Legal origin dummy, Revised anti-director rights index, culture variables]

The results are presented in Table 2. In Model 1 we study the impact of firm and country specific variables on the propensity of foreign firms to delist. Consistent with Doidge et al. (2010) we find that firms with growth opportunities (as measured by Market-to-Book) ${ }^{4}$ are less likely to delist likely because they need access to a well developed capital markets in order to finance their growth. Firms from civil law countries (associated with weaker investor protection) are more likely to delist. In Model 2 we add the impact of SOX and our results suggest that post-SOX, overall firms are more likely to terminate their ADR programs, consistent with Hypothesis 1.

Model 3 shows the interaction between country legal dummy variables and SOX and the results suggest that while firms from civil law countries are more likely to delist pre-SOX, post-SOX they are less likely to delist. These results can be explained possibly with the need for bonding with the stronger regulatory system and the overall poor market valuation in firms from civil law countries.

The impact of culture on the decision to delist is shown in Models 4 through 7 of Table 2. Model 4 shows that firms from countries that are culturally different from the U.S. are less likely to delist, consistent with Hypothesis 1 . This result is consistent with the notion that firms list shares in countries that are culturally similar (Sarkissian and Schill, 2003), investors prefer to invest in shares from countries that are familiar and cross-listing is a tool to create a level of familiarity of the foreign shares in the U.S. and to mitigate the home-bias of U.S. investors. Model 5 of Table 2 shows that this relationship is reversed post-SOX, consistent with Hypotheses 2. This result implies that the high costs of compliance with SOX regulation possibly lead to increase in foreign firm delisting shares from the U.S. Compliance with SOX is expensive for any firm however this cost is even higher for foreign firms that are culturally distant from the U.S. because SOX will likely mandate changes in the common business practices in addition to the legal, administrative and reporting fees.

Next, we study the impact of country individualism on the propensity of foreign firms to delist shares from the U.S. Model 6 in Table 2 shows that firms from individualistic societies have a higher

\footnotetext{
${ }^{4}$ Market-to-Book here is industry adjusted. In addition, all company specific variables, including Market-to-Book are "purged" from the impact of country specific variables. This is done by running a linear regression model with dependent variable each of the company specific variables, and a set of country specific explanatory variables. The residuals from this regression (first pass) were used in the logit model, which in fact is a "second pass" of the analysis presented here.
} 


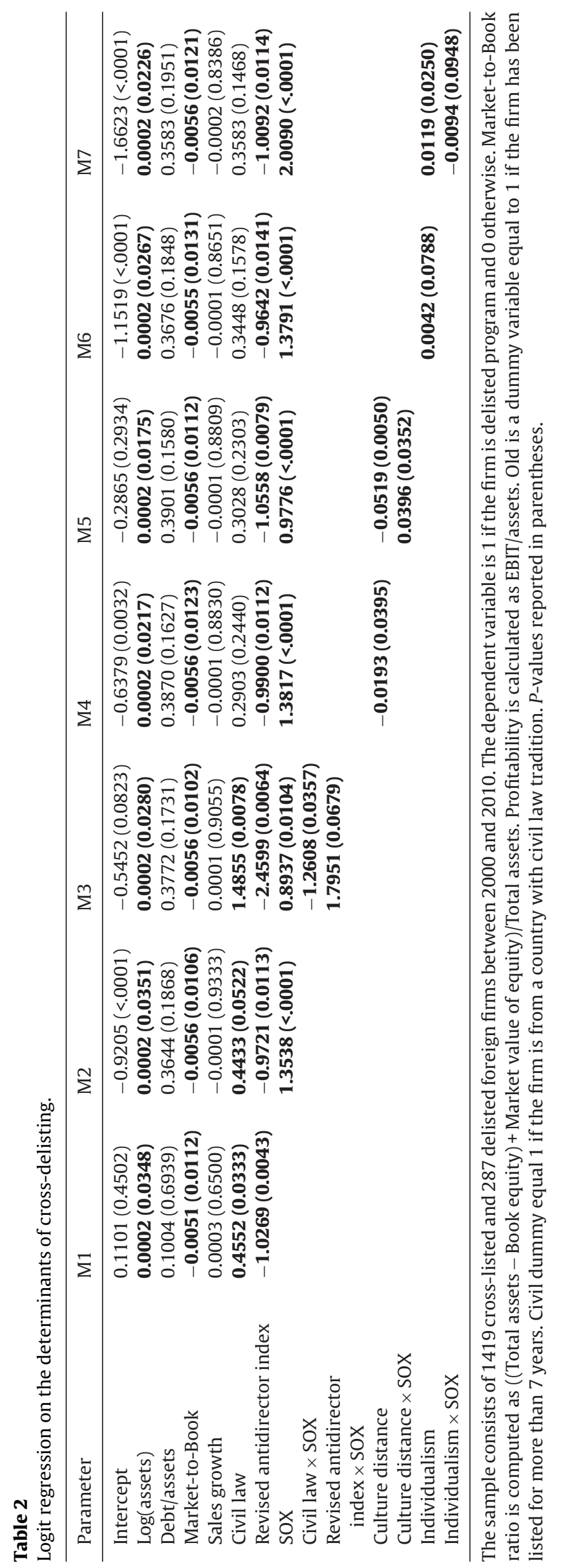


Table 3

Logit analysis on the likelihood of ADR terminations before and after SOX.

\begin{tabular}{lllll}
\hline Parameter & M1 & M2 & M3 & M4 \\
\hline Intercept & 2.2008 & 1.9397 & 0.4306 & 1.5778 \\
& $(<.0001)$ & $(0.0003)$ & $(0.3244)$ & $(<.0001)$ \\
Log(assets) & -0.0002 & $-\mathbf{0 . 0 0 0 3}$ & $-\mathbf{0 . 0 0 0 2}$ & $-\mathbf{0 . 0 0 0 2}$ \\
& $(0.1029)$ & $(\mathbf{0 . 0 3 5 2})$ & $\mathbf{( 0 . 0 1 3 9 )}$ & $(\mathbf{0 . 0 1 9 5 )}$ \\
Debt/assets & -1.2499 & -1.1744 & -0.6418 & -0.5714 \\
& $(0.1117)$ & $(0.1432)$ & $(0.1666)$ & $(0.2170)$ \\
Market-to-Book & 0.0112 & 0.0197 & 0.0177 & 0.0152 \\
& $(0.7348)$ & $(0.6975)$ & $(0.6124)$ & $(0.6272)$ \\
Sales growth & -0.0699 & -0.1038 & -0.0778 & -0.0786 \\
& $(0.7513)$ & $(0.6674)$ & $(0.5912)$ & $(0.6007)$ \\
Civil law & & $-\mathbf{1 . 3 2 5 7}$ & -0.7095 & -0.7952 \\
& & $(\mathbf{0 . 0 9 5 6 )}$ & $(0.1426)$ & $(0.0987)$ \\
Revised antidirector index & & 1.4187 & 1.2310 & 1.1879 \\
Culture distance & & $(0.2937)$ & $(0.1336)$ & $(0.1464)$ \\
Individualism & & & $\mathbf{0 . 0 4 0 7}$ & $\mathbf{( 0 . 0 4 0 0 )}$ \\
\end{tabular}

The sample consists of 287 firms that cross-delisted from USA between 2000 and 2010. The dependent variable is SOX equal to 1 if the firm cross-delisted after SOX and equal to 0 if the firm cross-delisted before SOX. The positive coefficient estimates of the explanatory variable indicate that the firm is more likely cross-delist after SOX and negative coefficient estimates indicate that the firm is less likely cross-delist after SOX and more likely to cross-delist before SOX. Market-to-Book ratio is computed as ((Total assets - Book equity) + Market value of equity)/Total assets. Old is a dummy variable equal to 1 if the firm has been listed for more than 6 years. Civil dummy equal 1 if the firm is from a country with civil law tradition. $P$-values reported in parentheses.

propensity to delist, consistent with our Hypothesis 3. That is explainable with the high level of confidence that even without the additional benefits of U.S. listing, foreign firms will be able to succeed in their home market. In addition, managers from individualistic societies are risk taking and proactive and likely will find other sources of capital hence they are confident about their success even without the extra boost of U.S. cross-listing.

Model 7 shows the impact of SOX on the delisting behavior of firms from individualistic countries. Post-SOX firms from countries with individualistic societies are less likely to delist, consistent with Hypothesis 4. Managers in individualistic countries tend to be overaggressive in their decisions, the individualistic mindset allows for more managerial opportunism and higher agency cost (Fidrmuc and Jacob, 2010) and possibly compliance with SOX mitigates the potential for agency conflicts and sends a strong signal to both domestic and U.S. investors. Furthermore, managerial confidence to a degree is related to persistence and faith in their past decision.

Next, we provide an alternative method for studying the impact of SOX on the delisting. We construct a subsample consisting only of firms that cross-delist. The purpose of this analysis is to study the company and country specific factors that determine the type of firms that would cross-delist program after SOX. For this purpose, we perform a logit regression analysis in which the dependent variable is SOX and the independent variables are country and company specific variables:

Likelihood of ADR termination after SOX $=f[\log ($ Assets), Debt/Assets, Market-to-Book,

Sales growth, Legal origin dummy, Country market quality variables, Culture variables]

The results are presented in Table 3. Model 1 shows that firms with high Market-to-Book are more likely to cross-delist after SOX. Model 2 shows that firms from civil law countries are less likely to delist post-SOX compared to pre-SOX. Model 3 shows that post-SOX firms from culturally distant countries from U.S. are more likely to delist, consistent with Hypothesis 3. Model 4 shows that firms from individualistic societies are less likely to delist post-SOX, consistent with our Hypothesis 4. 
This result is consistent with the bonding hypothesis. Civil law countries provide weaker protection for the minority shareholders, consistent with La Porta et al. (1998). In order to cross-list in the U.S. these firms have to comply with regulatory requirements of the U.S. and therefore "bond" themselves with a stronger governance system. It might be that the providers of capital in these firms require the U.S. cross-listing and also cross-listings help increase the reputation and trustworthiness of the firms.

\subsection{The impact of SOX on duration of ADR programs}

After analyzing the impact of SOX on the determinants of ADR terminations, we focus on the impact of SOX on the duration of existence of ADR terminations. This is performed using a time dependent hazard model. It measures the factors that impact the survival distribution function after a certain period of time $t$ :

$$
S(t)=\operatorname{Pr}(T \geq t)
$$

Survivors are existing cross-listed firms and non survivors are firms that have been present in the U.S. capital markets but have delisted. This is a time dependent hazard model which measured the impact of SOX on the duration of U.S. listings. The sample for this analysis consists of delisted firms that were initially listed in the U.S. pre-SOX. The hazard model provides comparison of the duration of listing for firms delisting pre-SOX to the duration of listing for firms delisting post-SOX. Both of these groups of firms are listed under the same circumstances (pre-SOX). The results are presented in Table $4 .{ }^{5}$ The status variable indicates the increased risk of failure, i.e. the increased propensity to delist over time. The significant negative SOX dummy indicates significant shortening of the time of the U.S. listing existence after SOX.

\subsection{Value impact of culture, SOX on the decision to cross-delist}

This section is focused on the value discount created by the ADR termination process. Previous research shows the cross-listing premium. Doidge et al. (2004) define the cross-listing premium as the increase in Market-to-Book for cross-listed foreign firms compared to non cross-listed foreign firms. In the case of cross-delisting, we expect the opposite effect - decrease in Market-to-Book for the delisting firms.

We use a mixed fixed and random effects regression (Henderson, 1990; Searle et al., 1992) in the following form:

$$
\mathbf{Y}=\mathbf{X} \boldsymbol{\beta}+\mathrm{Z} \boldsymbol{\gamma}+\boldsymbol{\varepsilon}
$$

In the above equation, $\mathbf{Y}$ is a vector $(N T \times 1)$ firm-year Market-to-Book multiples of cross-listed and delisted foreign firms over the sample period. $\mathbf{X}$ is a matrix of $(N T \times J)$ firm-country specific explanatory variables and the corresponding $(J \times 1)$ coefficient vector $\boldsymbol{\beta}$ represents the fixed effects. The set of firmcountry specific variables falls within two groups - the first group indicates the U.S. listing status of the firm (listed or delisted) and the second group - firm specific variables (such as sales growth, assets, leverage).

$\mathbf{Z}$ is a matrix of country dummy variables constructed as follows: each row in $Z$ consists of $K$ indicator variables which equal to 1 if the foreign firm is domiciled in country $k$ and 0 otherwise. $\gamma$ is a $(K \times 1)$ vector that represents the unknown random effects - the unobserved country-specific Marketto-Book valuation multiples. Therefore, $Z \gamma$ measures the difference in Market-to-Book multiples of foreign firms across countries.

The estimation is in two stages - in stage $1, \boldsymbol{\gamma}$ is estimated as linear projection of $\mathbf{Z}$ onto the space of $\mathbf{Y}$ and in the second stage $\boldsymbol{\beta}$ is estimated as a linear projection of the residual $\mathbf{Y}-\mathbf{Z} \boldsymbol{\gamma}$ on $\mathbf{X}$.

The results are presented in Table 5. The results show that the delisting discount persists after controlling for firms and country specific effects. Model 1 shows the higher Market-to-Book ratio of

${ }^{5}$ Due to data availability from Bank of New York this table is based on a sample from 2000 till 2004. 


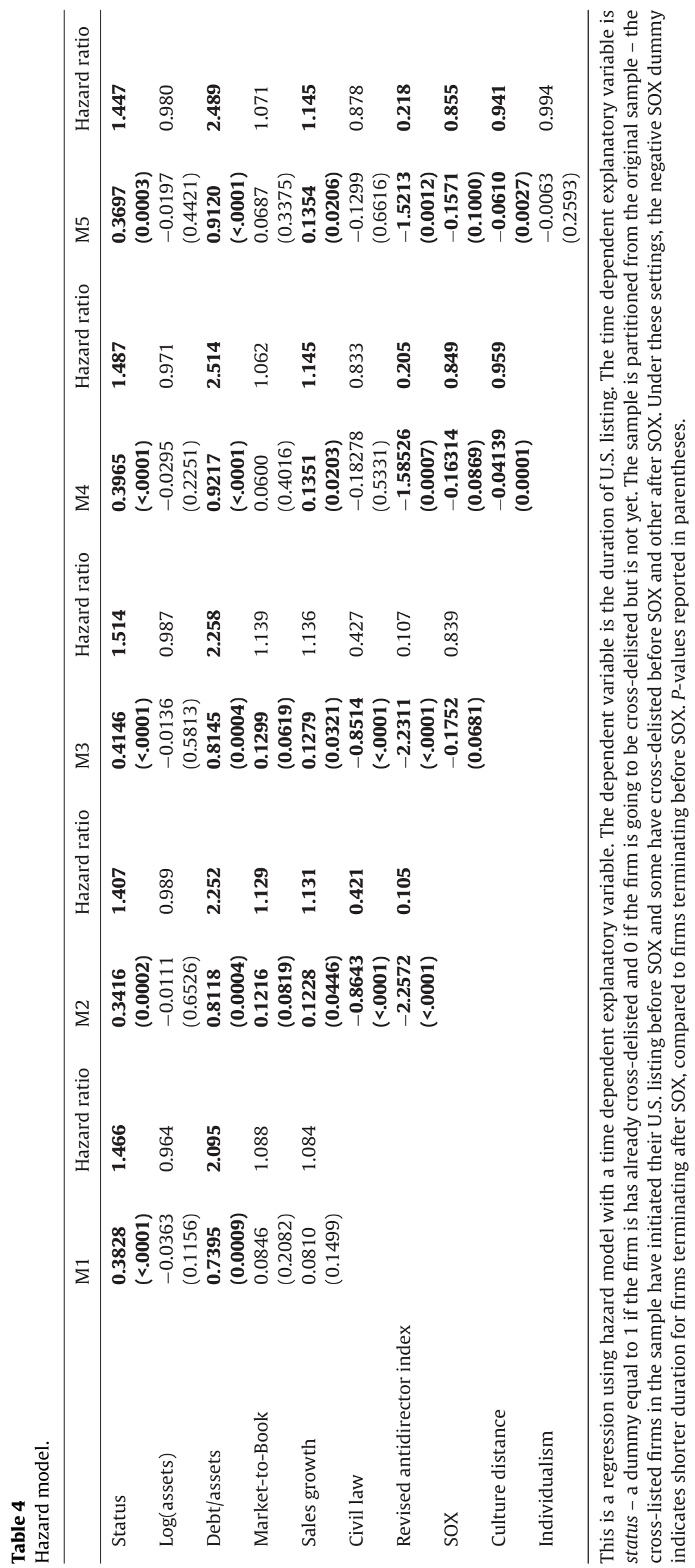


Table 5

Value regression of the delisting discount.

\begin{tabular}{|c|c|c|c|c|c|c|}
\hline & M1 & M2 & M3 & M4 & M5 & M6 \\
\hline Intercept & $\begin{array}{l}1.2246 \\
(<.0001)\end{array}$ & $\begin{array}{l}1.2244 \\
(<.0001)\end{array}$ & $\begin{array}{l}1.8198 \\
(<.0001)\end{array}$ & $\begin{array}{l}1.7214 \\
(<.0001)\end{array}$ & $\begin{array}{l}1.2766 \\
(<.0001)\end{array}$ & $\begin{array}{l}1.6693 \\
(<.0001)\end{array}$ \\
\hline Delist & $\begin{array}{l}-0.1424 \\
(<.0001)\end{array}$ & $\begin{array}{l}-0.1348 \\
(0.0957)\end{array}$ & $\begin{array}{l}-0.1449 \\
(<.0001)\end{array}$ & $\begin{array}{l}-0.0664 \\
(0.2900)\end{array}$ & $\begin{array}{l}-0.0879 \\
(0.3141)\end{array}$ & $\begin{array}{l}-0.0839 \\
(0.3366)\end{array}$ \\
\hline Individualism & $\begin{array}{l}0.0041 \\
(0.0277)\end{array}$ & $\begin{array}{l}0.0041 \\
(0.0276)\end{array}$ & & & $\begin{array}{l}0.0033 \\
(0.0824)\end{array}$ & \\
\hline Individualism $\times$ delist & & $\begin{array}{l}-0.0001 \\
(0.9193)\end{array}$ & & & & \\
\hline Culture distance & & & $\begin{array}{l}-0.0157 \\
(<.0001)\end{array}$ & $\begin{array}{l}-0.0175 \\
(0.0215)\end{array}$ & & $\begin{array}{l}-0.0134 \\
(0.0809)\end{array}$ \\
\hline Culture distance $\times$ delist & & & & $\begin{array}{l}-0.0062 \\
(0.1663)\end{array}$ & & \\
\hline Delist $\times$ SOX & & & & & $\begin{array}{l}-0.0633 \\
(0.4961)\end{array}$ & $\begin{array}{l}-0.0690 \\
(0.4583)\end{array}$ \\
\hline Individualism $\times$ SOX & & & & & $\begin{array}{l}0.0016 \\
(0.0001)\end{array}$ & \\
\hline Culture distance $\times$ SOX & & & & & & $\begin{array}{l}-0.0083 \\
(<.0001)\end{array}$ \\
\hline SOX & $\begin{array}{l}0.1055 \\
(<.0001)\end{array}$ & $\begin{array}{l}0.1056 \\
(<.0001)\end{array}$ & $\begin{array}{l}0.0972 \\
(<.0001)\end{array}$ & $\begin{array}{l}0.1054 \\
(<.0001)\end{array}$ & $\begin{array}{l}0.0131 \\
(0.6150)\end{array}$ & $\begin{array}{l}0.2112 \\
(<.0001)\end{array}$ \\
\hline Log(assets) & $\begin{array}{r}-0.0919 \\
(0.0003)\end{array}$ & $\begin{array}{l}-0.0919 \\
(0.0003)\end{array}$ & $\begin{array}{l}-0.0361 \\
(0.1452)\end{array}$ & $\begin{array}{l}-0.0920 \\
(0.0003)\end{array}$ & $\begin{array}{r}-0.0930 \\
(0.0003)\end{array}$ & $\begin{array}{l}-0.0935 \\
(0.0002)\end{array}$ \\
\hline Sales growth & $\begin{array}{l}-0.0005 \\
(<.0001)\end{array}$ & $\begin{array}{l}-0.0005 \\
(<.0001)\end{array}$ & $\begin{array}{l}-0.0004 \\
(<.0001)\end{array}$ & $\begin{array}{l}-0.0005 \\
(<.0001)\end{array}$ & $\begin{array}{l}-0.0005 \\
(<.0001)\end{array}$ & $\begin{array}{l}-0.0004 \\
(<.0001)\end{array}$ \\
\hline Civil law & $\begin{array}{l}0.1860 \\
(0.2022)\end{array}$ & $\begin{array}{l}0.1860 \\
(0.2021)\end{array}$ & $\begin{array}{l}0.2510 \\
(<.0001)\end{array}$ & $\begin{array}{l}0.1358 \\
(0.3641)\end{array}$ & $\begin{array}{l}0.1883 \\
(0.1972)\end{array}$ & $\begin{array}{l}0.1376 \\
(0.3588)\end{array}$ \\
\hline Revised antidirector index & $\begin{array}{l}-0.0612 \\
(0.8186)\end{array}$ & $\begin{array}{l}-0.0612 \\
(0.8187)\end{array}$ & $\begin{array}{l}-0.3296 \\
(<.0001)\end{array}$ & $\begin{array}{l}-0.0729 \\
(0.7828)\end{array}$ & $\begin{array}{l}-0.0641 \\
(0.8105)\end{array}$ & $\begin{array}{l}-0.0719 \\
(0.7862)\end{array}$ \\
\hline
\end{tabular}

The dependent variable in this regression is Market-to-Book. The independent variable delist is a dummy variable equal to 1 if the firm has cross-delisted and 0 otherwise. Therefore, delist dummy measure the addition or deduction to Market-to-Book due to the delisting process. The rest of the variables follow the definition in Table 3. P-values reported in parentheses.

firms from individualistic countries as expected. Model 2 of Table 5 suggests delisting firms from individualistic societies do not experience significant change in the delisting discount. Models 4 and 5 show that overall firms from countries culturally distant from U.S. experience very small (economically insignificant) discount in Market-to-Book and the degree of individualism does not significantly impact the delisting discount. Models 5 and 6 suggest that post-SOX firms from individualistic societies experience slight increase in Market-to-Book valuation and firms from culturally distant countries experience a decline in their valuation.

\section{Conclusion}

In this paper we provide an explanation of the determinants of ADR terminations and the impact of SOX on these determinants. Our results suggest that in addition to the financial and legal explanation, culture plays an important role in the delisting decisions of foreign firms. Furthermore, the interaction between culture distance and SOX may determine the attractiveness of U.S. capital markets. These findings are important because more than three quarters of the foreign countries (30 out of 39) with available culture indicator scores are culturally significantly different from U.S. The increased compliance costs of SOX may drive foreign firms to alternative locations to finance their growth and to increase their international reputation. However, it is clear the U.S. capital markets have not lost their attractiveness as an environment that provides opportunity for firms from countries with weaker investor protection to bond themselves with a stronger regulatory environment. The cultural aspects play just as important role in the decision of the firm to cross-list or delist. We found that the propensity to delist is lower for firms from countries with cultural similarities to the U.S. and higher for 
firms from individualistic societies. Interestingly, after the implementation of SOX we observed the "reversal of fortunes" in which foreign firms' delisting behavior if driven by the opposite forces.

\section{References}

Abdallah, W., Goergen, M., 2008. Does corporate control determine the cross-listing location? Journal of Corporate Finance 14 , 183-199.

Angel, J., Harris, J., Panchapagesan, V., Werner, I., 2004. From pink sleep to pink sheets: liquidity and shareholder wealth consequences of Nasdaq delisting. Working Paper Series at Charles A. Dice Center for Research in Financial number 2004-22, Ohio State University.

Akhigbe, A., Martin, A., Nishikawa, T., 2009. Changes in risk of foreign firms listed in the U.S. following Sarbanes-Oxley. Journal of Multinational Financial Management 19, 193-205.

Beugelsdijk, S., Frijns, B., 2010. A cultural explanation of the foreign bias in international asset allocation. Journal of Banking and Finance 34, 2121-2131.

Chakrabarti, R., Gupta-Mukherjee, S., Jayaraman, N., 2009. Mars-Venus marriages: culture and cross-border M\&A. Journal of International Business Studies 40, 216-236.

Chen, C., Chen, X., Meindl, J., 1998. Deciding on equity or parity: a test of situational, cultural, and individual factors. Journal of Organizational Behavior 19 (2), 115-129.

Chui, A.C., Titman, S., Wei, K.J., 2010. Individualism and momentum around the world. Journal of Finance 65, 361-392.

Coffee, J., 1999. The future as history: the prospects for global convergence in corporate governance and its implications. Northwestern University Law Review 93, 641-708.

Coffee, J., 2002. Racing towards the top? The impact of cross-listings an stock market competition on international corporate governance. Columbia Law Review 102, 1757-1831.

Djankov, S., La Porta, R., Lopez-de-Silanes, F., Schleifer, A., 2008. The law and economics of self-dealing. Journal of Financial Economics 88 (3), 430-465.

Doidge, C., 2004. U.S. cross-listings and the private benefits of control: evidence from dual class firms. Journal of Financial Economics 72, 519-593.

Doidge, C., Karolyi, A., Stulz, R., 2004. Why are foreign firms listed in the U.S. worth more? Journal of Financial Economics 71 , 205-238.

Doidge, C., Karolyi, A., Stulz, R., 2009a. Has New York become less competitive than London in global markets? Evaluating foreign listing choices over time. Journal of Financial Economics 91, 253-377.

Doidge, C., Karolyi, A., Lins, K., Miller, D., Stulz, R., 2009b. Private benefits of control, ownership and the cross-listing decision. The Journal of Finance 64 (1), 425-466.

Doidge, C., Karolyi, A., Stulz, R., 2010. Why do foreign firms leave U.S. equity markets? Journal of Finance 65 (4), $1507-1553$.

Ekanayake, S., 2004. Agency theory, national culture and management control systems. The Journal of American Academy of Business Cambridge 4, 49-54.

Erez, M., 1994. Toward a model of cross-cultural and organizational psychology. In: Handbook of Industrial and Organizational Psychology, vol. 4, 2nd ed. Consulting Psychologists Press, Palo Alto, CA, pp. 559-607.

Fidrmuc, J., Jacob, M., 2010. Culture, agency costs and dividends. Journal of Comparative Economics 38 (2), 321-339.

Fernandez, N., Ferreira, M., 2008. Does international cross-listing improve the information environment. Journal of Financial Economics 88, 216-244.

Foerster, L., Karolyi, G., 1999. The effects of market segmentation and investor recognition on asset prices: evidence from foreign stocks listing in the U.S. Journal of Finance 54, 981-1013.

Fuerst, O., 1998. A theoretical analysis of the investor protection regulations argument for global listing of stocks. Working Paper, International Center for Finance at Yale.

Gozzi, J., Levine, R., Schmukler, S., 2008. Internationalization and the evolution of corporate governance. Journal of Financial Economics 88, 607-632.

Henderson, C.,1990. Statistical method in animal improvement: historical overview. In: Advances in Statistical Methods for Genetic Improvement of Livestock. Springer-Verlag, New York, pp. 1-14.

Hofstede, G., 1980. Culture's Consequences - International Differences in Work Related Values. Sage Publications, Beverly Hills.

Hofstede, G., 1991. Cultures and Organizations: Software of the Mind: Intercultural Cooperation and Its Importance for Survival. McGraw-Hill, New York.

Hofstede, G., 2001. Culture's Consequences: Comparing Values, Behaviors, Institutions and Organizations Across Nations, 2nd ed. Sage Publications, London.

Hofstede, G., 2003. Culture's Consequences: Comparing Values, Behaviors, Institutions, and Organizations Across Nations. Sage Publications.

Huberman, G., 2001. Familiarity breeds investment. Review of Financial Studies 14, 659-680.

Johnson, N., Droege, S., 2004. Reflections on the generalization of agency theory: cross-cultural considerations. Human Resource Management Review 14, 325-335.

Kashima, Y., Callan, V., 1994. The Japanese workgroup. In: Triandis, H., Dunnette, M., Hough, L. (Eds.), Handbook of Industrial and Organizational Psychology, vol. 4, 2nd ed. Consulting Psychologists Press, Palo Alto, CA, pp. 606-649.

La Porta, R., Lopez-de-Silanes, F., Shleifer, A., Vishny, R., 1998. Law and finance. Journal of Political Economy 106, $1113-1155$.

Lee, H., Valero, M., 2010. Cross-listing effect on information environment of foreign firms: ADR type and country characteristics. Journal of Multinational Financial Management, 178-196.

Lel, U., Miller, D., 2008. International cross-listing, firm performance, and top management turnover: a test of the bonding hypothesis. The Journal of Finance 63 (4), 1897-1937.

Leuz, C., Triantis, A., Wang, T., 2008. Why do firms go dark? Causes and consequences of voluntary SEC deregistrations. Journal of Accounting and Economics 45 (2-3), 181-208.

Licht, A., 2003a. Cross-listing and corporate governance: bonding or avoiding? Chicago Journal of International Law 4. 
Licht, A., 2003b. Legal Plug-Ins: Cultural Distance, Cross-Listing and Corporate Governance Reform. Interdisciplinary Center (IDC) Herzliyah - Radzyner School of Law; European Corporate Governance Institute (ECGI).

Linck, J., Netter, J., Yang, T., 2009. The effects of unintended consequences of the Sarbanes-Oxley Act on the supply and demand for directors. The Review of Financial Studies 22 (8), 3281-3328.

Lins, K., Strickland, D., Zenner, M., 2003. Do non-U.S. firms issue equity on U.S. stock exchanges to relax capital constraints? Journal of Financial and Quantitative Analysis.

Litvak, K., 2007a. The effect of the Sarbanes-Oxley Act on non-US companies cross-listed in the U.S. Journal of Corporate Finance $13,195-228$.

Litvak, K., 2007b. Sarbanes-Oxley and the cross-listing premium. Michigan Law Review 105 (8), 1857-1898.

Liu, S., 2004. The impact of involuntary foreign delistings: an empirical analysis. Working Paper, Texas A\&M International University.

Loree, D., Guisinger, S., 1995. Policy and non-policy determinants of U.S. foreign direct investment. Journal of International Business Studies 26 (2), 281-299.

Marosi, A., Massoud, N., 2008. "You can enter but you cannot leave..." - U.S. securities markets and foreign firms. Journal of Finance 63 (5), 2477-2506.

Marosi, A., Massoud, N., 2007. Why do firms go dark? Journal of Financial and Quantitative Analysis 42 (2), 421-442.

Miller, D., 1999. The market reaction to international cross-listing: evidence from depositary receipt. Journal of Financial Economics 51, 103-123.

Morris, M., Menon, T., Ames, D., 2001. Culturally conferred conceptions of agency: a key to social perception of persons, groups, and other actors. Personality and Social Psychology Review 5, 169-182.

Muchinsky, P., 2000. Emotions in the workplace: The neglect of organizational behavior. Journal of Organizational Behavior 21 (7), 801-805.

North, D., 1990. A Transaction Cost Theory of Politics. Journal of Theoretical Politics 2 (4), 355-367.

Pagano, M., Randl, A., Roell, A., Zechner, J., 2001. What makes stock exchanges succeed? Evidence from cross-listing decisions. European Economic Review 45, 770-782.

Pagano, M., Randl, A., Roell, A., Zechner, J., 2002. The geography of equity listing: why do companies list abroad. Journal of Finance 57 (6), 2651-2694.

Perino, M., 2005. Enron's legislative aftermath: some reflections on the deterrence aspects of the Sarbanes-0xley act of 2002. Columbia Law and Economics Working Paper No. 212; St. John's Legal Studies Research Paper.

Piotroski, J., Srinivasan, S., 2008. The Sarbanes-Oxley Act and the flow of international listings. Journal of Accounting Research $46(2), 383-426$.

Portes, R., Rey, H., 2000. The determinants of cross-border flows: the geography of information. University of California, Berkeley, Center for International Development \& Economic Research (CIDER), Working Paper C00-111, 2000.

Pozen, R., 2004. Can European companies escape U.S. listings? Harvard Law and Economics Discussion Paper No. 464.

Rauch, J., 2001. Business and social networks in international trade. Journal of Economic Literature 39, 1177-1203.

Reese, W., Weisbach, M., 2002. Protection of minority shareholder interests, cross-listings in the United states, and subsequent equity offerings. Journal of Financial Economics 66, 65-104.

Ribstein, L., 2003. International implications of Sarbanes-Oxley: raising the rent on U.S. law. Journal of Corporate Law Studies $3(2)$.

Sanger, G., Peterson, J., 1990. An empirical analysis of common stock delistings. Journal of Financial and Quantitative Analysis $25(2)$.

Sarkissian, S., Schill, M., 2003. The overseas listing decision: new evidence of proximity preference. Review of Financial Studies 17 (3), 769-809.

Searle, S.R., Casella, G., McCulloch, C.E., 1992. Variance Components. John Wiley \& Sons, Inc., New York.

Sethi, S., Guisinger, S., Phelan, S., Berg, D., 2003. Trends in foreign direct investments flows: a theoretical and empirical analysis. Journal of International Business Studies 34 (4), 315-326.

Siegel, J., 2005. Can foreign firms bond themselves effectively by renting U.S. securities laws. Journal of Financial Economics 75 , 319-359.

Shupp, R., Williams, A., 2008. Risk preference differentials of small groups and individuals. The Economic Journal 118 (525), $258-283$.

Triandis, H., Vassiliou, V., 1972. Interpersonal influence and employee selection in two cultures. Journal of Applied Psychology $56,140-145$.

Williamson, O., 2000. The new institutional economics: taking stock, looking ahead. Journal of Economic Literature 38 (3), 595-613.

Wintoki, B., 2007. Corporate boards and regulation: the effects of the Sarbanes-Oxley Act and the exchange listing requirements on firm value. Journal of Corporate Finance 13, 229-250.

Witmer, J., 2006. Why do firms cross-(de)list? An Examination of the determinants and effects of cross-delisting. Working Paper, Bank of Canada.

Zhang, I., 2007. Economic consequences of the Sarbanes-Oxley Act of 2002. Journal of Accounting and Economics 44, 74-115. 